\title{
Seroprevalence of Mycoplasmosis in Goats of North West Agroclimatic Zone of Tamil Nadu in Organised and Unorganised Sector
}

\author{
R. Rishikesavan*, K.M. Palanivel, S. Saravanan, P. Suresh and S. Sivaseelan \\ Department of Veterinary Preventive Medicine, Veterinary College and Research Institute, \\ Namakkal-637002, India \\ Tamil Nadu Veterinary and Animal Sciences University, Chenna-600 051, India \\ *Corresponding author
}

\section{A B S T R A C T}

Keywords

Goats, CCPP,

Seroprevalence, iELISA, Tamilnadu

Article Info

Accepted:

10 October 2019

Available Online:

10 November 2019
244 serum samples from unorganized sector and 122 serum samples from organized sector were collected from apparently healthy goats of different age and sex from North Western agroclimatic zone of Tamilnadu (India) and were screened for Mycoplasmal antibodies by employing Indirect Enzyme linked Immunosorbent Assay. Sixty two out of 244 serum samples from unorganized goat farms in five districts were found positive which indicating overall seroprevalence of 25.40. Out of 122 serum samples from organized goat farms 35 samples were positive for Mycoplasma infection with percent positivity of 28.68. The Indirect Enzyme linked Immunosorbent assay for Mycoplasmal antibodies detection was found to be simple, reliable with having high sensitivity and specificity.

\section{Introduction}

The goat is an important commodity in many areas of the world, where is kept as a source of meat, milk and fiber. Often described as "poor man's cow, the goats can survive in areas where cow cannot and, therefore replaces the cow in importance for a large segment of the world's population. Of the 81.43 million goats in Tamil Nadu, 12.56 million are present in north western agro climatic zone and the state meat production from goats was figured to
43350 tonnes during 2013-14 which was the largest red meat production (DAH, Government of Tamil Nadu Census,2014).. Mycoplasmal infections in goats result in significant losses and morbidity and mortality may reach $100 \%$. Mycoplasmas are smallest fastidious bacteria which can cause diseases in major species of animals. Diagnosing Mycoplasma infection in goat flock by serological assay is the simple method and less time consuming when conventional culture isolation. Hence seroprevalence was 
assessed by employing Indirect Enzyme linked immune sorbent assay (iELISA).

\section{Materials and Methods}

This study was carried out in Department of Veterinary Preventive Medicine, Veterinary College and Research Institute, Namakkal, Tamil Nadu from August 2015 to April 2019. Sera samples were randomly collected from organized and unorganized goat farms in various district of North Western Agro climatic Zone of Tamil Nadu. Details of the samples collected from goats to detect seroprevalence of Mycoplasma are given in Table 1.

Seroprevalence for Mycoplasma capricolum capripnuemoniae (Mccp) was carried out by using the IDEXX, Switzerland iIELISA kit. iELISA protocol was employed as per the manufacturer's procedures. ELISA reading was carried out in BIORAD ${ }^{\circledR}$ ELISA reader at $450 \mathrm{~nm}$ wave length. Samples with Percentage of Inhibition less than 55\% were considered as negative and samples with Percentage of Inhibition greater than or equal to $55 \%$ were considered as positive.

\section{Results and Discussion}

\section{Seroprevalence of Mycoplasma infection in} organized goat farms

Out of 122 serum samples from organized goat farms 35 samples were positive for Mycoplasma infection with percent positivity of 28.68. A total of 44, 44 and 34 samples from PGRIAS (Kattuppakkam), Livestock Farm Complex (LFC, VCRI, Namakkal) and MSRS (Mechheri) respectively were tested and the seropositivity was $43.18,11.76$ and 27.7 percent respectively. However, PGRIAS were exposed to the infection is higher of 43.8 percent and followed by 27.7 in MSRS and 11.76 percent in LFC, VCRI, Namakkal respectively.

\section{Seroprevalence of Mycoplasma infection in unorganized goat farms}

The samples from unorganized goat farms from Krishnagiri, Dharmapuri, Salem, Namakkal and Perambalur districts of Tamil Nadu were furnished in Table 1. Sixty two out of 244 serum samples from unorganized goat farms in five districts were found positive with percent positivity of 25.40 .

The seroprevalence of Mycoplasma infection was found to be 26.92, 32.14, 21.42, 26.92 and 14.29 percent in Namakkal, Dharmapuri, Salem, Krishnagiri and Perambalur districts respectively. The seropositivity of Mycoplasma infection is higher in Dharmapuri district followed by Namakkal district and lowest in Perambalur district.

Out of 122 serum samples from organized goat farms 35 samples were positive for Mycoplasma infection with per cent positivity of 28.68. The goats maintained at PGRIAS, Kattuppakkam were exposed to the infection is higher of 43.8 per cent as the purchase of Boer breed for the farm for upgradation with native breed might have introduced the Mycoplasma organism and seroconversion.

The findings of this study are also in accordance with the findings of Swai et al., (2013) Ingle et al., (2000) who found 9.6 per cent prevalence of CCPP in goats in two districts of northern Tanzania by using the same type of cELISA kit and) Ingle et al., (2000) who found and 33.11 prevalence in goats Nagpur District, India. 
Table.1 Seroprevalence of Mycoplasma infection in organized and unorganized goat farms in North Western zone of Tamil Nadu by ELISA

\begin{tabular}{|c|c|c|c|c|c|c|c|}
\hline \multicolumn{4}{|c|}{ Organized sector } & \multicolumn{3}{c|}{ Unorganized sector } \\
\hline Farms & $\begin{array}{c}\text { No of } \\
\text { samples } \\
\text { tested }\end{array}$ & $\begin{array}{c}\text { No. of } \\
\text { samples } \\
\text { positive }\end{array}$ & $\begin{array}{c}\text { \% } \\
\text { positive }\end{array}$ & Districts & $\begin{array}{c}\text { No of } \\
\text { samples } \\
\text { tested }\end{array}$ & $\begin{array}{c}\text { No. of } \\
\text { samples } \\
\text { positive }\end{array}$ & $\begin{array}{c}\% \\
\text { positive }\end{array}$ \\
\hline LFC & 34 & 4 & 11.76 & Namakkal & 52 & 14 & 26.92 \\
\hline MSRS & 44 & 12 & 27.70 & Dharmapuri & 56 & 18 & 32.14 \\
\hline PGRIAS & 44 & 19 & 43.18 & Salem & 56 & 12 & 21.42 \\
\hline Total & $\mathbf{1 2 2}$ & $\mathbf{3 5}$ & $\mathbf{2 8 . 6 8}$ & Krishnagiri & 52 & 14 & 26.92 \\
\hline & & & & Perambalur & 28 & 04 & 14.29 \\
\cline { 5 - 9 } & & & & Total & $\mathbf{2 4 4}$ & $\mathbf{6 2}$ & $\mathbf{2 5 . 4 0}$ \\
\hline
\end{tabular}

Shahzad et al., (2016) reported the seroprevalence of CCPP as 8.52 per cent by employing monoclonal antibody-based competitive enzyme-linked immunosorbent assay (cELISA) for the specific measurement of antibodies to Mycoplasma capricolum subsp. capripneumoniae (Mccp) bacterium. Hadish et al., (2009) reported 32.66 per cent sero-prevalence of CCPP in goats of Ethiopia. High prevalence of mycoplasma antibodies was also reported by Ashish Roy, et al., (2010) as $42.50 \%$ in goats of Gujarth.. Rana et al., (2009) reported $78 \%$ sero positivity by employing iELISA.

Out of 244 serum samples from unorganized goat farms 62 samples were positive for Mycoplasma infection with per cent positivity of 25.40. Goats from Dharmapuri district have shown higher seropositivity of 32.14 per cent. The present results are in agreement with the study of Larios-Hernández et al., (2017) who found the seroprevalence of Mycoplasma mycoides subspecies mycoides (Mmm) using a competitive ELISA (c-ELISA) from 556 goats sampled in random was 11.2 per cent seropositivity in Mexico.

In present finding indicates endemicity of infection in North Western Agro climatic Zone of Tamil Nadu and appropriate measures to be taken for regular screening, therapeutic and prophylactic measures for containment of caprine mycoplasmosis.

\section{References}

Ashish Roy, Kumar Pankaj and Bhanderi, B. (2010). Detection of Mycoplasma capri antibodies in goats of Gujarat state. Vet. World.,3(10):471-472.

Hadish, B., Eshetu, L., Mengistu, W and Hailesilassie, M. (2009). Seroprevalence of contagious caprine pleuropneumonia in Kefta Humera, Alamata (Tigray) and Abaala (Afar), Northern Ethiopia. Trop. Anim.Heal.Prod., 41:803-806.

Ingle, V.C., Shivkumar, P., Kalorey, D.R., Pote, D.E. and Jadhav, M.B. (2008). Seroprevalence of CCPP in Nagpur district of Vidarbha region. Ind. J. FieldVeterinar., 4 :48- 50.

Larios-Hernández S. M, D.I. MartínezHerrera, J.J. Martinez-Maya, F. Aguilar-Romero, J.F. MoralesAlvarez, R.Flores-Castro and R. Lascurain R, (2017). Serological evidence of Mycoplasma mycoides subspecies mycoides in the Central Area of Veracruz, Mexico. Pak Vet J. 37: 165-169.

Rana, R., Mehra, M., Kumar, V., Kumar, A. and Vihan, V.S. (2009). 
Seroprevalence of CCPP in goats using native $M$. capri isolates. Ind.Vet.J., 86: 115-117.

Shahzad, W., T. Yaqoob, N. Mukhtar, R. Munir, R. Ahmad, M. S. Khan and A. Hussain, (2016). Sero-prevalence of Mycoplasma capricolum subsp. capripneumoniae in goats through cELISA in different districts of
Punjab, Pakistan The J. Anim. \& Plant Scien.,26: 931-937

Swai, E.S., J. E. Kaaya and E.Y. Noah, (2013). Antibody response to Mycoplasma capricolum subsp. capripneumoniae bacterium in small holder dairy goats in Tanzania. Trop. Anim. Health. Prod., 45:1603-8.

\section{How to cite this article:}

Rishikesavan, R., K. M. Palanivel, S. Saravanan, P. Suresh and Sivaseelan, S. 2019. Seroprevalence of Mycoplasmosis in Goats of North West Agroclimatic Zone of Tamil Nadu in Organised and Unorganised Sector. Int.J.Curr.Microbiol.App.Sci. 8(11): 991-994.

doi: https://doi.org/10.20546/ijcmas.2019.811.116 